BIOFARM

Jurnal Ilmiah Pertanian

ISSN Print: 0216-5430; ISSN Online: 2301-6442

Vol. 16, No. 2, Oktober 2020

\title{
Aplikasi Limbah Cair Tebu Terhadap Pertumbuhan Bibit Kelapa Sawit (Elaeis guineensis jacq.) pada Fase Pre Nursery
}

\section{Liquid Waste Application From Sugar Mill on the Growth of Palm Oil (Elaeis guineensis jacq.) Seeds in the Pre Nursery Phase}

\author{
Saktiyono Sigit Tri Pamungkas ${ }^{* 1}$ dan Yoga Adiguna ${ }^{1}$ \\ Politeknik LPP Yogyakarta \\ *Korespondensi Penulis: skt@polteklpp.ac.id
}

\section{ABSTRAK}

Tujuan penelitian ini untuk mengetahui pengaruh limbah cair tebu yang optimal bagi pertumbuhan bibit kelapa sawit di fase pre nursery (PN). Penelitian ini menggunakan metode Rancangan Acak Kelompok non factorial. Dosis hasil fermentasi limbah cair tebu merupakan factor yang dicobakan, terdiri dari T0 (control), T20 (20 ml), T40 (40 ml), T60 (60 ml) dan T80 (80 ml), masing-masing diulang sebanyak 3 kali dalam 1 blok, sehingga total diperoleh 45 unit. Analisa data menggunakan ANOVA dengan taraf kepercayaan 95\% yang dilanjutkan dengan uji Duncan Multiple Range Test (DMRT). Parameter yang diamati adalah tinggi tanaman $(\mathrm{cm})$, jumlah daun (helai) dan Panjang akar terpanjang $(\mathrm{cm})$. Hasil penelitian menunjukan bahwa aplikasi limbah cair tebu belum memberikan pengaruh yang optimal pada semua parameter pada pembibitan kelapa sawit di fase PN. Hasil terbaik ditunjukan pada T0 (tanpa perlakuan atau control)

Kata Kunci: limbah cair tebu, pembibitan, pre nursery

\begin{abstract}
The purpose of this study was to determine the effect liquid waste from sugar mill with optimal doses that can be has a good influence on the growth of palm oil seedlings. This research was arranged non factorial Randomized Block Design method. The doses of liquid waste drops from sugar mill is a tried and tested factor, TO (control), T1 (20 ml), 2 (40 ml), T3 (60 ml), T4 $(80 \mathrm{ml})$. the treatment was repeated 3 times in a one block, so that has total 45 unit. Data was analyzed by ANOVA at 95\% significance level further by Duncan Multiple Range Test (DMRT) testing. Parameters were observed is plant height (cm), number of leaves and longest roots length $(\mathrm{cm})$. the result showed that liquid waste application had no optimal effect for all parameters on the growth in pre nursery phase. Best result shown on TO (control)
\end{abstract}

Key Words: liquid waste (sugarcane drops), seedlings, pre nursery

\section{PENDAHULUAN}

Pengembangan kelapa sawit memerlukan lahan sebagai aspek yang cukup penting. Kelapa sawit memiliki syarat kesesuaian lahan agar dapat berproduksi secara optimum. Namun, kecenderungan praktik perkebunan yang semakin terdesak ke arah lahan marginal, menuntut pengembangan teknologi agar kelapa sawit tetap dapat berproduksi optimum di lahan marginal tersebut (Pahan, 2011). Ada dua sistem pembibitan kecambah kelapa sawit, yaitu sistem dua tahap dan sistem satu tahap. Pembibitan dua tahap terdiri atas pembibitan awal (Pre Nursery) dalam kantong plastik kecil hingga bibit berumur $3-4$ bulan baru dilanjutkan dalam pembibitan utama (mainnursery) menggunakan kantong plastik besar hingga bibit berumur $10-14$ bulan. Sedangkan pembibitan satu tahap, kecambah langsung ditanam dalam kantong plastik besar hingga umur siap dipindahkan ke lapang. Pembibitan merupakn tahap awal pengelolaan tanaman yang akan di diusahakan. Pertumbuhan bibit yang baik merupakan faktor utama untuk memperoleh tanaman yang baik di lapangan. Berdasarkan hal tersebut, maka pembibitan perlu di tanganisecara optimal. Upaya yang dapat di lakukan yaitu dengan penambahan pupuk organik dan anorganik.

Pupuk organik merupakan pupuk yang berasal dari berbagai bahan pembuat pupuk alami seperti kotoran hewan, bagian tubuh hewan, tumbuhan, yang kaya akan mineral serta baik untuk pemanfaatan penyuburan tanah, salah satu bentuknya adalah pupuk cair. 
Pupuk organik cair merupakan larutan yang berisi satu atau lebih zat yang dibutuhkan oleh tanaman yang mudah larut. Pupuk ini berasal dari larutan pembusukan sisa tanaman, kotoran hewan dan manusia. Pupuk organik cair mengandung unsur hara Fosfor, Nitrogen, dan Kalium yang di butuhkan oleh tanaman, serta memperbaiki struktur tanah dan mikroorganisme di dalam tanah. Menurut hasil penelitian Muhsin (2011), kandungan pupuk organik cair limbah tebu yaitu, Fosfor (P) 1,57\%, Nitrogen (N) 0,93\%, dan Kalium (K) 0,30\%. Penggunaan pupuk organik cair lebih mudah dan efisien karena mampu memberikan hara sesuai kebutuhan tanaman. Pemberian pupuk organik cair dapat lebih merata dan kepekatannya dapat diatur sesuai kebutuhan. Berdasarkan penelitian Siboro (2013), tentang pembuatan pupuk cair dan biogas dari campuran limbah sayuran hasil optimal dengan komposisi EM4 $350 \mathrm{ml}$, yaitu unsur $\mathrm{N}$ $1 \%$, P $1.98 \%$, K20.85\%. Dalam pembuatan pupuk organik cair dibutuhkan bahan-bahan yang mengandung unsur-unsur seperti Nitrogen, Carbon, Pospor dan Kalium. Salah satu tanaman yang mengandung unsur Kalium adalah lamtoro, pada daun lamtoro dapat ditemukan kandungan Kalium yang cukup.

Tetes tebu (molasses) termasuk produk samping pabrik gula. Tetes merupakan sisa sirup terakhir dari stasiun masakan yang telah dipisahkan gulanya melalui kristalisasi berulangkali sehingga tidak mungkin lagi menghasilkan gula dengan kristalisasi konvensional. Tetes diproduksi sekitar 4,5\% dari tebu. Selain dapat digunakan sebagai pupuk dan pakan ternak, tetes dapat juga digunakan sebagai bahan baku fermentasi yang dapat menghasilkan etanol, asam asetat, asam sitrat,monosodium glutamat (MSG), asam laktat, dan lain-lain. Tetes tebu merupakan sumber karbon dan nitrogen bagi ragi yang melalui proses fermentasi. Prinsip fermentasi adalah proses pemecahan senyawa organik menjadi senyawa sederhana yang melibatkan mikroorganisme. Mikroorganisme ini berfungsi untuk menjaga keseimbangan karbon $(\mathrm{C})$ dan nitrogen $(\mathrm{N})$ yang merupakan faktor penentu keberhasilan dalam proses fermentasi (Jainurti, 2016). Sumber energi yang paling bagus untuk fermentasi yaitu molasse dibandingkan gula pasir dan gula jawa dan hasil penelitian menunjukkan lama waktu fermentasi yang optimal yaitu 14 hari dengan hasil nitrogen yaitu $3.745 \%$ pada penggunaan molasse sebanyak 50 ml. Kusmiati (2007) menambahkan molasse mengandung nutrisi yang cukup tinggi untuk kebutuhan mikroorganisme, sehingga dapat dijadikan bahan alternatif untuk sumber energi dalam media fermentasi. Sumber energi berguna untuk pertumbuhan sel mikroorganisme.

\section{METODE PENELITIAN}

Penelitian di laksanakan di green house politeknik LPP Yogyakarta jl. LPP 1A, Balapam, Klitren, Gondokusuman, Yogyakarta. Pada tanggal 09 Januari 2018 09 April 2018, dengan ketinggian tempat lokasi penelitian $155 \mathrm{mdpl}$.

Rancangan percobaan yang digunakan adalah rancangan acak lengkap (RAL) non faktorial yang terdiri dari 5 perlakuan, 3 kali ulangan sebagai blok, sehingga terdapat 15 unit percobaan masing-masing unit percobaan terdiri 3 bibit sawit, sehingga total terdapat 45 bibit tanaman. Perlakuan tersebut terdiri atas $\mathrm{T} 0$ : kontrol, $\mathrm{T} 1$ : tetes $20 \mathrm{ml}, \mathrm{T} 2$ : tetes $40 \mathrm{ml}, \mathrm{T} 3$ : tetes $60 \mathrm{ml}$ dan $\mathrm{T} 4$ : tetes $80 \mathrm{ml}$.

Variabel yang diamati adalah tinggi tanaman (cm), jumlah daun (helai), akar terpanjang $(\mathrm{cm})$. Analisis data yang digunakan adalah analisis ragam (ANOVA) pada tingkat signifikan $95 \%$. Apabila terdapat beda nyata antara perlakuan, maka dilanjutkan menggunakan uji jarak berganda.

\section{HASIL DAN PEMBAHASAN}

Hasil analisa ragam (anova) menunjukkan adanya beda nyata, maka dilakukan uji lanjut dengan menggunakan Duncan Multiple Range Test (DMRT) dengan taraf kesalahan $5 \%$.

\section{Tinggi Tanaman}

Bedasarkan Tabel 1 menujukan bahwa perlakuan T0 (kontrol) memiliki hasil rata-rata paling baik yaitu $9,97 \mathrm{~cm}$, dibandingkan perlakuan T20, T40, T60, T80 yang masingmasing memiliki nilai $9,08 \mathrm{~cm}, 6,58 \mathrm{~cm}, 5,06$ $\mathrm{cm}, 4,49 \mathrm{~cm}$.

Pada Gambar 1 menunjukan bahwa penambahan tinggi bibit sawit pada perlakuan T0 (kontrol) lebih tinggi dari semua perlakuan yaitu $3,97 \mathrm{~cm}$ dan hasil yang terendah adalah perlakuan T80 yaitu $4,49 \mathrm{~cm}$. Pada perlakuan T0 (kontrol) menghasilkan rata-rata tinggi tanaman bibit sawit lebih besar dibandingkan dengan semua perlakuan, hal ini disebabkan kandungan unsur $\mathrm{N}$ (nitrogen) dalam tanah tercukupi sehingga tanaman dapat menyerap 
Tabel 1. Hasil analisa DMRT Pemanfaatan Hasil Limbah Tetes Tebu Terhadap Pertumbuhan Bibit Tanaman Kelapa Sawit (Eleais guineensis Jacq) Pada Pre Nursery

\begin{tabular}{|c|c|c|c|c|c|}
\hline Perlakuan & TT & JD & PA & BB & BK \\
\hline T0 & $9,97 c$ & $2,69 c$ & $19,47 b$ & $3,48 c$ & $1,10 \mathrm{c}$ \\
\hline T20ml & $9,08 \mathrm{c}$ & $2,56 c$ & $20,76 b$ & $4,00 c$ & $1,17 \mathrm{c}$ \\
\hline $\mathrm{T} 40 \mathrm{ml}$ & $6,58 b$ & $2,16 b$ & $14,60 a b$ & $2,00 b$ & $0,57 b$ \\
\hline T60ml & $5,06 a b$ & $1,73 a$ & $11,81 a$ & $1,45 a b$ & $0,42 a b$ \\
\hline T80ml & $4,49 a$ & $1,47 a$ & $10,01 a$ & $1,03 a$ & $0,29 a$ \\
\hline Fhit T & 1,24 & 1,838 & 1,029 & 0,624 & 1,682 \\
\hline
\end{tabular}

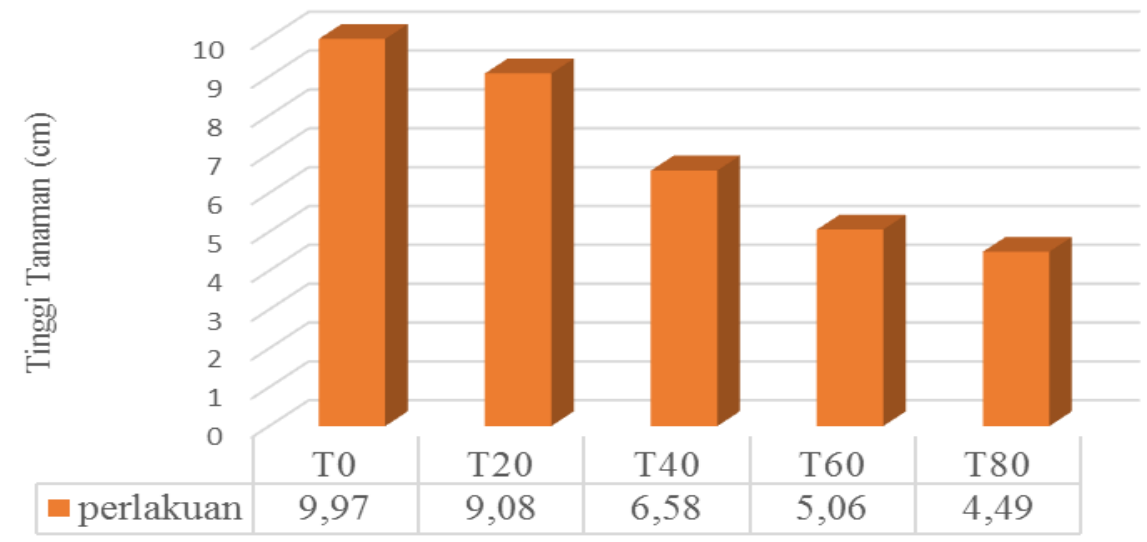

Gambar 1. Tinggi tanaman bibit sawit PN

unsur hara dengan baik. Menurut Juniarti (2016) dan Harjadi (1993), Kandungan unsur hara nitrogen yang berlebihan akan menurunkan kemampuan fotosintesis bagi tanaman. Apabila karbohidrat berkurang pembelahan sel menjadi lambat maka perkembangan organ tanaman menjadi lambat. Ketersediaan unsur hara yang cukup pada tanah mempengaruhi pertumbuhan vegetatif tanaman seperti tinggi tanaman dan jumlah daun, hal ini disebabkan karena pembentukan sel-sel baru dalam suatu tanaman sangat erat hubungannya dengan ketersediaan hara makro dan mikro yang cukup pada tanah. Oleh karena itu, maka penetapan konsentrasi dan dosis pupuk cair (POC) sangat penting dilakukan karena akan berpengaruh pada pertumbuhan jika tidak sesuai kebutuhan tanaman lebih khusus pada fase vegetative (Foth, 1998).

Pada penelitian ini perlakuan T80 memiliki rerata tinggi tanaman yang paling rendah, hal ini diduga pada perlakuan T80 mendapat tambahan unsur hara NPK dari POC yang berlebihan, sehingga dapat menghambat pertumbuhan tanaman. Menurut
Parman (2007) menyatakan bahwa pemberian pupuk NPK dengan dosis yang berlebihan justru akan mengakibatkan timbulnya gejala kelayuan pada tanaman, demikian juga dengan pernyataan Lubis (2008), bahwa pemberian pupuk cair dengan kandungan NPK tinggi pada bibit akan memberikan pengaruh terhadap partumbuhan vegetatif (menekan pertumbuhan). Selain itu, diduga bahwa dalam fermentasi yang menggunakan bahan air kelapa yang mengandung senyawa fenolik dapat menghambat pertumbuhan tanaman, hal ini sejalan dengan penelitian Chairani (1997), yang menyatakan bahwa terhambatnya pertumbuhan tunas melalui perendaman rimpang dalam larutan air kelapa ini diduga karena dalam air kelapa mengandung senyawa fenolik berupa asam benzoik yang dapat menghambat pertumbuhan lebih khususnya menghambat proses pemanjangan sel. Sebaliknya pada perlakuan T0 memiliki rerata tinggi tanaman yang paling baik, hal ini dikarenakan aplikasi POC di lakukan saat pembibitan pre nursery. Pembibitan pre nursery memiliki kondisi 
media tanam yang sebenarnya sudah ideal, faktor hara dalam kondisi tersedia, air yang cukup mengakibatkan terdorongnya sel-sel meristematis pada ujung bibit untuk melakukan pembesaran sel. Menurut Bonner dan Galston (1951, dalam Parman, 2007) pembelahan sel secara antiklinal dan periklinal dipengaruhi oleh zat pengatur tumbuh endogen yaitu auksin selain dari hara yang tersedia. Penambahan tinggi tanaman tidak hanya dipengaruhi oleh hormon tumbuhan dan NPK saja, akan tetapi dipengaruhi oleh hara mikro lainnya yaitu Magnesium (Mg) dan Calsium (Ca), tanpa adanya faktor pembatas lainnya maka pertumbuhan tinggi tanaman pada perlakuan T0 menjadi paling baik, hal ini di duga pada perlakuan lain jumlah hara mikro sebagai pembatas pertumbuhan bibit kelapa sawit.

Selain itu, terdapat faktor pendukung dalam pertumbuhan bibit kelapa sawit yang baik selain dipengaruhi oleh kandungan nutrisi juga dipengaruhi oleh kondisi lingkungan di dalam media pemeliharaan, dalam penelitian ini faktor lingkungan berpengaruh terhadap tinggi tanaman salah satunya cahaya, kurangnya cahaya matahari dapat menghambat proses fotosintesis, sehingga pertumbuhan tanaman juga terhambat, hal ini sejalan dengan guritno (1995) menyatakan bahwa pada parameter tinggi tanaman sangat sensitif terhadap faktor lingkungan tertentu seperti cahaya. Peran cahaya tidak hanya mutlak untuk fotosintesis, namun cahaya juga akan merangsang gerak fototropisme pada bibit tanaman (Salisbury dan Ross, 2005).

\section{Jumlah Daun}

Bedasarkan Tabel 1 menujukan bahwa perlakuan T0 (Kontrol) memiliki hasil rata-rata yang baik yaitu 2,69 helai, dibandingkan perlakuan T20, T40, T60, T80 yang masing-masing memiliki nilai 2,56 helai, 2,16 helai, 1,73 helai, 1,47 helai.

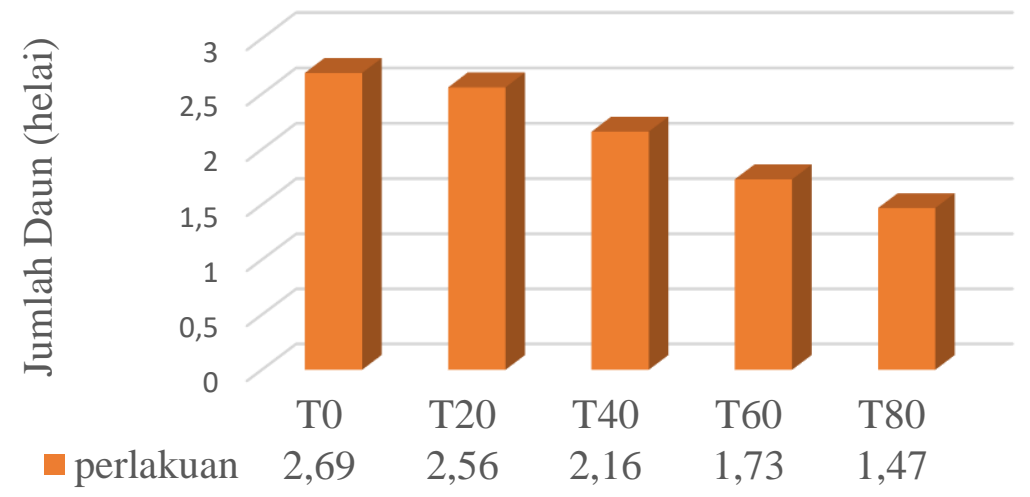

Gambar 2. Penambahan jumlah daun bibit sawit PN

Pada Gambar 2 menunjukan bahwa penambahan jumlah daun bibit sawit pada perlakuan TO (kontrol) lebih banyak dari semua perlakuan yaitu 2,69 helai dan hasil yang terendah adalah perlakuan T80 yaitu 1.47 helai. Keadaan ini dikarenakan unsur hara nitrogen dalam tanah sudah tercukupi oleh tanaman sehingga tanaman sudah tercukupi. Menurut Sutedjo dan Kartasapoetra (1991) menyatakan bahwa fungsi nitrogen antara lain untuk meningkatkan pertumbuhan daun. Jumlah pelepah berkaitan dengan tinggi tanaman, semakin tinggi tanaman maka semakin banyak jumlah pelepah yang terbentuk karena daun keluar dari nodusnodus yakni tempat kedudukan daun yang ada pada batang. Jumlah daun dipengaruhi oleh tinggi tunas, karena pertumbuhan tunas membentuk batang semu yang merupakan pelepah daun yang membungkus satu sama lain. Jumlah daun menunjang pertumbuhan, karena daun merupakan tempat utama terjadinya fotosintesis (Nugroho, 2012). Pernyataan tersebut sejalan dengan dengan penelitian ini bahwa semakin tinggi tanaman semakin banyak jumlah daunnya. Pada perlakuan T80 penambahan jumlah daun paling rendah yaitu 1,47 helai, hal ini dikarenakan dalam penyerapan unsur hara yang belum optimal. Menurut Novizan (2005) pemupukan yang berlebihan dapat menyebabkan penyerapan unsur-unsur lain (unsur mikro) terhambat sehingga dapat menyebabkan kekurangan unsur misalnya kelebihan $\mathrm{K}$ pada larutan tanah akan menekan penyerapan $\mathrm{Mg}$ sehingga menjadi faktor pembatas, hal ini menyebabkan pada T80 memiliki rata-rata penambahan jumlah daun paling rendah. Pernyataan tersebut sejalan dengan penelitian Slamet (1991), bahwa kekurangan magnesium dapat mempengaruhi jumlah daun, padahal jumlah 
dan luas daun merupakan salah satu indikator pertumbuhan dan perkembangan bibit tanaman. Selain itu, diduga hormon sitokinin berperan dalam pembentukan tunas tunas untuk daun dan pelepah. Arah transpor sitokinin berbeda dengan transpor auksin, sitokinin hanya di sintesis di ujung-ujung akar kemudian di transpor ke nodus-nodus untuk percabangan dan daun. Mekanisme ini akan terjadi apabila transpor auksin sudah berjalan sempurna (T0) dari ujung tanaman ke seluruh tanaman.

Perlakuan T0 diduga tidak terdapat faktor pembatas, hal ini menunjukan bahwa kebutuhan hara makro dan mikro untuk pertumbuhan terpenuhi. Unsur hara mikro Mg, $\mathrm{Mn}, \mathrm{Ca}$, Fe dan $\mathrm{Zn}$ dibutuhkan dalam jumlah kecil akan tetapi wajib tersedia. Unsur-unsur mikro tersebut merupakan katalisator sintesis protein yang khusus dalam pembentukan material daun dan klorofil (Poerwowidodo, 1992 dalam Puspadewi et all, 2016). Protein yang terbentuk merupakan penyusun utama protoplasma daun dan klorofil sehingga akan meningkatkan aktivitas sebaran fotosintat untuk perkembangan jaringan meristematik pada tunas, daun dan percabangan.

\section{Panjang Akar Terpanjang}

Bedasarkan Tabel 1 menujukan bahwa perlakuan T20 memiliki hasil rata-rata yang baik yaitu $20.76 \mathrm{~cm}$ apabila dibandingkan perlakuan T0 (kontrol), T40, T60, T80 yang masing-masing memiliki nilai $19,47 \mathrm{~cm}, 14.60$ $\mathrm{cm}, 11,81 \mathrm{~cm}, 10,01 \mathrm{~cm}$.

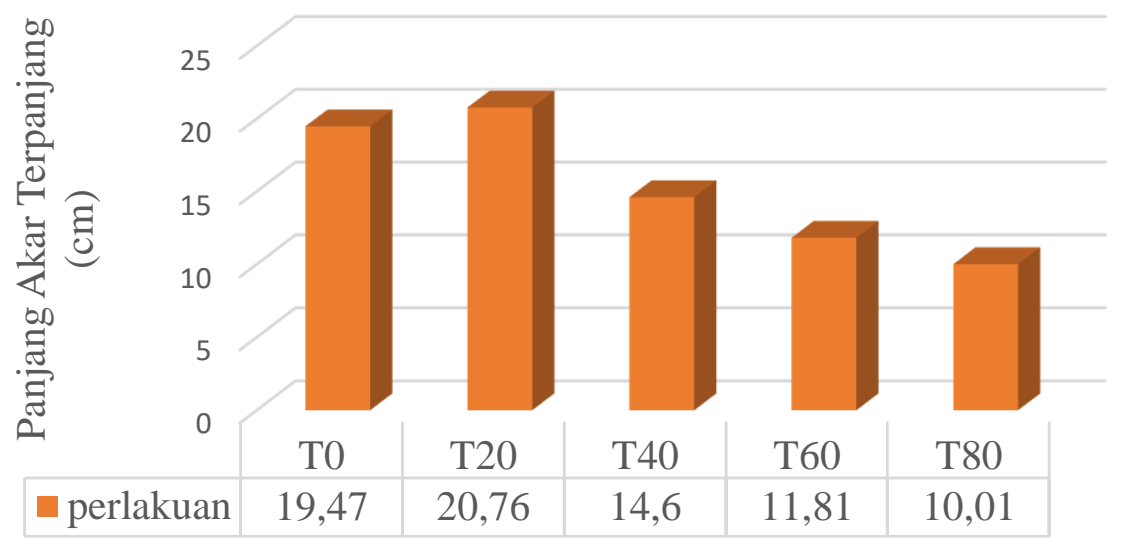

Gambar 3. Penambahan panjang akar terpanjang bibit sawit $P N$

Pada Gambar 3 menunjukan bahwa penambahan panjang akar terpanjang bibit sawit pada perlakuan T20 lebih panjang dari semua perlakuan yaitu $20,76 \mathrm{~cm}$ dan hasil yang terendah adalah perlakuan T80 yaitu $10,01 \mathrm{~cm}$, hal ini disebabkan karena dalam kandungan fermentasi tetes tebu menjadi POC mengandung hormon auksin yang berasal dari air kelapa. Hormon auksin yang terdapat dalam air kelapa dapat dapat merangsang pertumbuhan sel pada akar bibit sawit. Hormon tumbuh merupakan senyawa organik ataupun anorganik yang dalam konsentrasi rendah akan memacu pertumbuhan salah satu organ tanaman, akan tetapi dalam konsentrasi yang tinggi akan menghambat pertumbuhan tanaman. Pada perlakuan T20 diduga berada pada kondisi terbaik dalam aktifasi auksin untuk mempengaruhi pertumbuhan akar tanaman.

Menurut Yunanda (2015) bahwa auksin yang diberikan ke tanaman akan dialokasikan ke bagian bawah (transport auksin) untuk membantu perkembangan akar. Selain unsur hara, akar membutuhkan tambahan hormon tumbuh yang cukup untuk pertumbuhan dan perkembangannya, jumlah auksin yang tepat mengakibatkan sel-sel maristematik pada ujung pangkal akar terus membelah dan terdiferensiasi menjadi akar-akar. Penelitian Destalia (2017) menyatakan bahwa penambahan zat pengatur tumbuh eksogen pada tanaman akan meningkatkan pertumbuhan dari suatu tanaman termasuk dalam proses inisiasi akar yang akan berpengaruh pada perpanjangan akar tanaman.

Sedangkan pada perlakuan T80 menunjukkan hasil yang paling rendah, hal ini disebabkan terlalu banyak hormon auksin yang diterima tanaman, menyebabkan akar tidak merespon sehingga pertumbuhan akar dan tanaman terhambat. Menurut Gardner, (1991) menyatakan bahwa respon auksin berhubungan dengan konsentrasinya. Konsentrasi yang tinggi bersifat menghambat pertumbuhan akar, hal lain disebabkan karena pada konsentrasi auksin yang tinggi, pembesaran sel berlangsung cepat sehingga ukuran sel menjadi besar. 
Keadaan ini akan menyebabkan reaksi turgor dalam sel sehingga permeabilitas sel terganggu dan sel akan mengalami kondisi kekurangan cairan. Penelitian ini sejalan dengan Aslamsyah (2002), menyatakan bahwa jika konsentrasi yang diberikan lebih tinggi dari pada konsentrasi optimum maka dapat mengganggu metabolisme dan perkembangan tumbuhan bibit tanaman.

\section{KESIMPULAN}

Berdasarkan hasil penelitian dan pembahasan dapat diperoleh kesimpulan sebagai berikut:

1. Pemberian Pupuk Organik Cair (POC) tetes tebu memberikan pengaruh sangat nyata terhadap pertumbuhan bibit kelapa sawit pre nursery.

2. Pemberian Pupuk Organik Cair (POC) tetes tebu pada perlakuan T20 (dosis $20 \mathrm{ml}$ ) memiliki hasil paling baik pada variabel panjang akar terpanjang $(\mathrm{cm})$, bobot basah (gram) dan bobot kering (gram).

3. Pemberian Pupuk Organik Cair (POC) tetes tebu pada perlakuan T0 (kontrol) memiliki hasil paling baik pada variabel tinggi tanaman $(\mathrm{cm})$ dan jumlah daun (helai).

\section{DAFTAR PUSTAKA}

Chairani, Fauzi. 1997. Pengaruh Larutan Air Kelapa Terhadap Penurunan Tunas Rimpang Jahe. Buletin Tanaman Rempah dan Obat (II) No.2. Bogor: Balai Penelitian Tanaman Rempah dan Obat.

Destalia 2017. Komposisi Atonik dan Air Kelapa pada Pertumbuhan Bud Chip Tebu (Saccahum officinarum I)

Foth. 1998.Dasar-Dasar IImu Tanah. Gadjah Mada University Press, Yogyakarta.

Gardner, F.P., R.B. Pearce. 1991. Fisiologi Tanaman Budidaya. Universitas Indonesia Press. Jakarta.

Harjadi, S.S. 2009. Zat Pengatur Tumbuh. Penebar Swadaya. Jakarta.
Jainurti. 2016.Pengaruh Penambahan Tetes Tebu (molasse) Pada Fermentasi Urin Sapi Terhadap Pertumbuhan Bayam Merah.(Skripsi) Universitas Sanata Dharma. Yogyakarta.

Kusmiati, Swasono, R. Tamat, Eddy, J. Dan Ria, I. 2007. Produksi Glukan Dari Dua Galur Agrobacterium sp. Pada Media Mengandung Kombinasi Molase Dan Urasil, Jurnal Biodiversitas.

Lubis, A. U. 2008. Kelapa Sawit (Elaeis guineensis Jacq.) Di Indonesia. Edisi 2. PPKS RISPA. Medan.

Muhsin, Ahmad. 2011. Pemanfaatan Limbah Hasil Pengolahan Pabrik Tebu Blotong Menjadi Pupuk Organik. Industrial Engineering Conference 201, hal 1-9. dilaksanakan 5 November 2011

Novizann. 2005. Petunjuk Pemupukan Yang Efektif. Agro Media Pustaka, Jakarta.

Nugroho, Hartanto; Purnomo dan Issirep Sumardi 2012. Struktur dan Perkembangan Tumbuhan. Jakarta: Penebar Swadaya.

Pahan, I. 2015. Panduan Teknis Budidaya Kelapa Sawit untuk Praktisi Kebun. Penebar Swadaya. Jakarta.

Parman, S., 2007, Pengaruh Pemberian Pupuk Organik Cair terhadap Pertumbuhan dan Produksi Kentang (Solanum tuberosum L.), Buletin Anatomi dan Fisiologi,15 (2), 21-31.

Puspadewi, S., W. Suntari dan Kusumiyati. 2016. Pengaruh Konsentrasi Pupuk Organik Cair (POC) dan Pupuk NPK terhadap Pertumbuhan dan Hasil Tanaman Jagung Manis (Zea mays L.) Kultivar Talenta. Jurnal Kultivasi Vol: 15 No. 3

Salisbury, F.B dan C.W. Ross. 2005. Plant Physiologi. Terjemahan. Norwalk: Easton Press.

Sutedjo, Mulyani. 2010. Pupuk dan Cara Pemupukan: Rineka Cipta. Jakarta. 